\title{
Study Habits and Attitudes of Freshmen Students: Implications for Academic Intervention Programs
}

\author{
Luisa Baquiran Aquino \\ University Research Pool, University of Saint Louis, Tuguegarao City, Philippines \\ Email: luisaaquino031580@gmail.com
}

\begin{abstract}
The substantive aim of this study was to investigate the favorable and unfavorable study habits and study attitudes of the freshmen students and determine its implications in formulating academic intervention programs. The Survey of Study Habits and Attitudes (SSHA) instrument developed by Brown and Holtzman (1969) was used to assess the study habits and attitudes of the students. Results show that students generally do not approve teacher methods and classroom management, and have inefficient time management. Favorable and unfavorable study habits and attitudes of the students were also revealed. Implications of these findings were discussed and the theory of confluent education was considered in designing a framework of academic intervention programs among HEIs.
\end{abstract}

Index Terms - study habits, study attitudes, study orientation, academic achievement, academic intervention programs, confluent education

\section{INTRODUCTION}

A great deal of research literature provides an evidence that study habits and study attitudes are both significant variables which determine the academic performance of students $[3,5,9,12,15]$.Yet, in spite of the perceived importance of study habits and study attitudes to educational achievement, very little attention were given by academic institutions to improve these factors. This is manifested from the very low understanding level and the equally poor and deteriorating knowledge of many students which is still a great concern of educators, parents and governments [15].This problem is pointed out by Hurlburt, et.al [8] as contextual and systemic: it is rooted in the educational process shared by students and schools.

Consequently, the need to improve student's study habits and attitudes is deemed necessary to improve student's academic achievement. Accordingly, it is essential for schools to determine factors which affect these characteristics adversely propose remedial measures and employ strategies for the development of good study habits and study attitudes [9].This is further supported by Hurlburt, et.al. [8] from their study which suggested that a confluent educational philosophy (systemic and holistic) and using confluent educational strategies (through which students' social-emotional and personal empowerment needs are met) may enhance the school experience, improve study habits and attitudes, and ameliorate the high dropout rate among the students.

The premise that improving study habits and attitudes will lead to academic success, this study is conducted. It aimed to provide comparison data on the study habits and attitudes of the high achievers and underachievers and consider the implications of these findings in designing academic intervention programs. This will lead to the identification of negative study habits of students which may affect their educational achievement. Understanding these negative characteristics will help lay the foundation of developing academic intervention programs as implications of confluent educational strategies that will help develop good study habits and study attitudes among the students [15].

Very few studies have compared the study orientation (study habits and attitudes) possessed by different groups of college students, such as those with high GPAs versus low GPAs. The study of Proctor, et. al [14] signified the importance of this line of research for several reasons. They pointed out that identifying characteristics that differentiate among groups of students would be helpful to know in which areas certain groups of students are likely to require remediation. In addition, acknowledging all of the variables that differentiate between high- and low-performing students furthers theoretical understanding of why some students succeed in college while others fail. Accordingly, this expanded understanding of all the factors that contribute to college success (and failure). This is important for the purposes of prediction (e.g., of who is likely to succeed in college) [5, 12], identification (e.g., of students in need of intervention), and remediation (e.g., of skills that can be improved and have been linked to academic success) [14].

A review of literature reveals methods that will improve student's study habits and attitudes. Table 1 presents these strategies which congruently describes approaches to confluent education. 
TABLE 1

FAVORABLE STUDY ORIENTATION AND ACADEMIC INTERVENTIONS

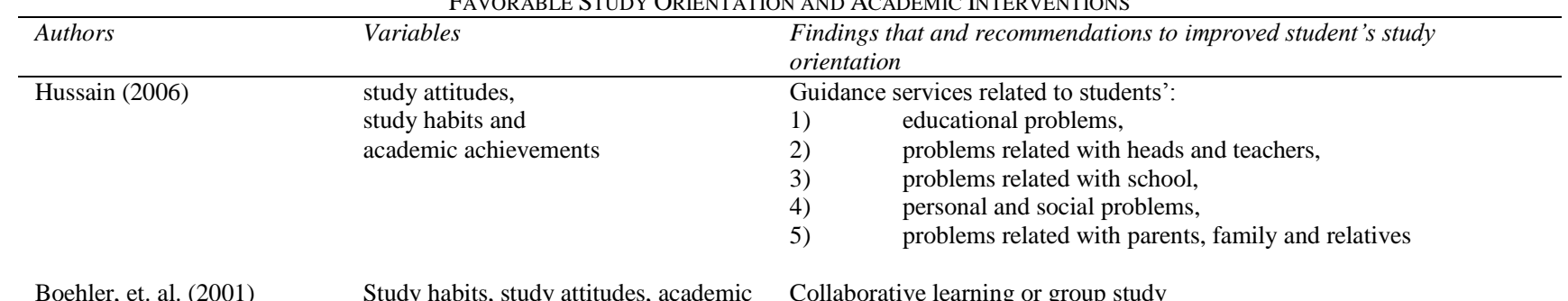

achievement, group study

Riaz, Kiran, Malik (2002) Educational achievements; Schedule of study; Study habits

Patrick, Furlow, Donovan (1988)

Wai-yung and Lailing (1984)

Awang and Sinnadurai (2010)

Keller (1978)
Academic intervention programs, retention, high risk students

Study skills, academic achievement study attitudes, academic performance study orientation skills, study habits,
Following a schedule of work, writing back the classroom material and taking class notes

Academic intervention programs have included the provision of remediation courses, study skills and reading comprehension courses, academic learning centers, orientation programs, academic advising, and personal counseling.

Learn how to study course

Study Orientation Skills training

Institutional or environmental factors such as university and divisional requirements, faculty teaching and examination procedures, residence hall atmosphere, background in English, and the quality of academic advising.

\section{THEORETICAL FRAMEWORK}

The theory of confluent education is a vital consideration in determining strategies to improve student's study habits and study attitudes. Confluent education as described by Hackbarth [7] is the type of learning intended to produce a sense of wholeness in people and society. Literature suggests that, as cited in the study of Hurlburt, et.al. [8], confluent education holds promise as an educational philosophy that can address issues of identity, self-worth, interpersonal relationships, and societal pressures. The said authors describes this as systemic in orientation, meaning, students should not be regarded as objects to be molded into predetermined forms; rather students and teachers should work together to achieve a mutually empowering learning experience. This implies that students should be educated as a whole person in all aspects which includes his intrapersonal, interpersonal, and societal development [5].

Moreover, literature suggests that, as cited in the study of Crede and Kuncel [5], study habits and study attitudes are multidimensional in nature [6]. This means that effective studying requires not only that the students possess knowledge of appropriate studying techniques and practices (study skills), but also sustained and deliberate effort (study motivation), self-regulation, ability to concentrate, self-monitoring (study habits), and sense of responsibility for and value in one's own learning (study attitude) [5]).

With this premise, this paper considered the implications of the study habits and study attitudes of the students to confluent education to provide a valuable note in designing a framework for academic intervention programs among HEIs.

\section{METHOD}

Stratified random sampling was used to determine the 313 student respondents. They represented the different freshmen students taking different courses (nursing, engineering, accounting, commerce, IT, education, etc.). Respondents were classified as high achievers (90 and above GPA) and low achievers (82-below GPA).

The Survey of Study Habits and Attitudes (SSHA), Form H developed by Brown \& Holtzman (1969) was used to measure student's study habits and study attitudes. The questionnaire consists of 100 items with 25 items on each SSHA scales namely; delay avoidance, work methods, teacher approval, and education acceptance. As defined in the study of Hurlburt, Koeker and Gade [7], the seven educational values in the SSHA instrument are defined as follows:

a) Delay Avoidance- a measure of the degree to which a student is prompt in completing assignments and is efficient in time management.

b) Work Methods- a measure of effective study skills.

c) Teacher Approval- a measure of student opinions about teacher classroom behavior and methods.

d) Educational Acceptance- a measure of student approval of educational objectives, practices, and requirements.

e) Study Habits- a combined score of the Delay Avoidance and Work Methods scales.

f) Study Attitudes- a combination of the scores of the Teacher Approval and Educational Acceptance scales. 
g) Study Orientation- an overall measure of a student's study habits and attitudes.

Means, frequency count and normative percentile ranks on each of the seven scales were used to compare the study habits and study attitudes of the high, average and low achievers and the positive and negative study orientation of the respondents.

\section{Results}

Of the 313 freshman students, 18 students are high achievers and 295 are low achievers. This suggests that only few numbers of students excel in their academics in the university.

Table 1 compares the means and standard deviations of the high and low achievers on study orientation. The result shows that the mean score of the high achievers on study orientation is higher compared to the low achievers. This implies that the high achievers have better study orientation than the low achievers. Furthermore, the high achievers have better score on all subcategories; study habits, study attitudes, delay avoidance, work method, attitude towards teacher and attitude towards education as depicted in Table 2.

TABLE 2

MEAN SCORE AND STANDARD DEVIATION ON SSHA SCALES

\begin{tabular}{|l|c|c|c|c|c|c|}
\hline \multirow{2}{*}{\multicolumn{1}{c}{ Scale }} & \multicolumn{3}{c|}{ HIGH ACHIEVERS } & \multicolumn{3}{c|}{ LOW ACHIEVERS } \\
\cline { 2 - 7 } & $\mathrm{N}$ & Mean & SD & $\mathrm{N}$ & Mean & SD \\
\hline Delay Avoidance & 18 & 20.2222 & 7.36091 & 295 & 15.6644 & 6.61676 \\
\hline Work Methods & 18 & 27.2222 & 10.03263 & 295 & 17.0407 & 7.51043 \\
\hline Teacher Approval & 18 & 20.6111 & 7.35758 & 295 & 15.0136 & 6.29975 \\
\hline Educational Acceptance & 18 & 27.3333 & 9.39962 & 295 & 17.5695 & 7.40388 \\
\hline Study Habits & 18 & 47.4444 & 16.63173 & 295 & 32.7051 & 12.89246 \\
\hline Study Attitudes & 18 & 47.9444 & 15.76098 & 295 & 32.5831 & 12.45724 \\
\hline Study Orientation & 18 & 95.3889 & 30.72485 & 295 & 65.2881 & 23.58704 \\
\hline
\end{tabular}

Table 1 further shows that students scored higher in work methods and educational acceptance compared to the other two scales (delay avoidance and teacher approval). This implies that students exert more effort in their study skills (work methods) and favors educational objectives and practices (educational acceptance).

In contrast, students obtained lower mean score on the scales delay avoidance and teacher approval. This connotes that generally the students are not prompt in completing their requirements and do not have efficient time management and do not favor teacher classroom behavior and methods.

TABLE 3

PERCENTILE SCORES ON SSHA SCALES

\begin{tabular}{|l|c|c|c|c|c|c|}
\cline { 2 - 7 } \multicolumn{1}{c|}{} & \multicolumn{3}{c|}{ High Achievers } & \multicolumn{3}{c|}{ Low Achievers } \\
\hline & $\begin{array}{c}\text { Mean } \\
\text { Score }\end{array}$ & Percentile Rank & $\begin{array}{c}\text { Interpretative } \\
\text { Value }\end{array}$ & $\begin{array}{c}\text { Mean } \\
\text { Score }\end{array}$ & $\begin{array}{c}\text { Percentile } \\
\text { Rank }\end{array}$ & Interpretative Value \\
\hline Delay Avoidance & 20.2222 & $50-60$ & Average High & 15.6644 & $35-45$ & Average Low \\
\hline Work Methods & 27.2222 & $65-75$ & Average High & 17.0407 & $35-45$ & Average Low \\
\hline Teacher Approval & 20.6111 & $25-30$ & Below Average & 15.0136 & $10-20$ & Below Average Low \\
\hline Educational Acceptance & 27.3333 & $50-60$ & Average High & 17.5695 & $10-20$ & Below Average Low \\
\hline Study Habits & 47.4444 & $50-60$ & Average High & 32.7051 & $25-30$ & Below Average \\
\hline Study Attitudes & 47.9444 & $35-45$ & Average Low & 32.5831 & $10-20$ & Below Average Low \\
\hline Study Orientation & 95.3889 & $35-45$ & Average Low & 65.2881 & $20-$ - 1 & Below Average Low \\
\hline
\end{tabular}

There are some significant revelations in the study habits and attitudes of the high and low achievers as revealed in Table 3. The table illustrates the mean scores under the different SSHA scales and compared to the percentile norm found in the SSHA manual. Under Delay Avoidance, the high achievers scored between $50^{\text {th }}$ and $60^{\text {th }}$ percentile which indicates an average level while the low achievers scored between $35^{\text {th }}$ and $45^{\text {th }}$ percentile that signifies an average low level. There were large differences in the percentile ranks between the high and low achievers under Work Method scale, with the former scoring on the average high level $\left(65^{\text {th }}\right.$ to $75^{\text {th }}$ percentile) and the latter at the average low level $\left(35^{\text {th }}\right.$ to $45^{\text {th }}$ percentile). On Teacher Approval, both high and low achievers do not approve teacher's classroom management and methods as revealed in their very low percentile rank of $25^{\text {th }}$ to $30^{\text {th }}$ and $10^{\text {th }}$ to $20^{\text {th }}$ respectively. There is also great discrepancy on the Educational Acceptance of the high and low achievers with the former scoring on average level $\left(50^{\text {th }}\right.$ to $60^{\text {th }}$ percentile) and the latter on below average low level ( $10^{\text {th }}$ to $20^{\text {th }}$ percentile).

The study habits of the high achievers scored on average high while the low achievers on below average. This means that the high achievers have better study habits than the low achievers. However, the study attitudes of both high and low achievers do not show good implication as revealed in their scores of average low and below average low level respectively. Moreover, the study orientation of both groups does not reveal promising results. The high achievers scored on the average low level and the low achievers scored on below average low level. This implies that generally both groups do not have favorable study orientation. 
Some significant revelations were found from the favorable and unfavorable characteristics of the freshmen. Favorable attitudes most noted were students utilizing their vacant hour so as to reduce evening work; taking few minutes to review answers before passing their examination paper; working hard to make a good grade even if they don't like the subject, studying three or more hours per day outside of class; organizing their work at the beginning of their study to utilize the time most effectively; giving special attention to neatness on reports, assignments and other work to be turned in among others.

Unfavorable study habits and attitudes were mostly found under delay avoidance, work methods and teacher approval. Among the noted negative or unfavorable study habits of the low achievers under delay avoidance were: sometimes quitting or studying only the easier parts of the lesson; sometimes distracted about daydreaming and future plans, wasting too much time talking, reading magazines, listening to the radio, watching TV, going to the movies, etc. for the good of their studies. On work methods, low achievers frequently memorize grammatical rules, definition of technical terms, formulas, etc. without really understanding them, have difficulty in expressing themselves and have trouble with the mechanics of English, skip figures, graphs and tables in a reading assignment and hesitate to ask the teacher for further explanation on an assignment that is not clear to them. On teacher approval, the low achievers think that their teachers like to exercise their authority too much; feel that teachers are too rigid and narrow-minded; believe that their teachers fail to give sufficient explanation; feel that teachers are arrogant and conceited among many others.

\section{DISCUSSION}

The study reveals that among the freshman respondents a significant number belongs to the underachievers. Riaz, et al. [15] and Patrick et al., [13] describes this as a prevailing situation characterized by students with low understanding level and accompanied by discouraging achievements. Further, the study shows that the high achievers have better study habits and attitudes as compared to low achievers. Similar results have been described by Sarwar, et al. [16], Crede and Kuncel [5], Hurlburt, et al. [8], Riaz, et al. [15].

Based on the results, one of the most marked problems was in the area of teacher approval. This is in accordance with the study of Hurlburt, Koeker and Gade [8] where most of the Native Indian students were generally less positive on opinions about teacher classroom behavior and method. This finding demonstrates the presence of poor teacher-student relations and reveals that students do not approve teacher methods and management. This result was significant. The meta-analysis on study habits conducted by Crede and Kuncel [5] pointed out that academic anxiety was found to be an important negative predictor of performance. This means that the students are generally affected by the academic requirements given by teachers which in turn affect their academic achievement. This problem emphasizes the role of the teacher in improving student's academic success. Wai-yung and Lailing [18] cited that teachers are inclined to tell students what to learn but generally neglect to instruct students about how to learn.

Another negative area was under the scale of delay avoidance. It implied that most of the respondents are not prompt in submitting their assignment and are not efficient in their time management. Same results were discussed in the study of Nourian, et al. [11] and Stark [17] were time management was one of the marked problems. Low achievers in this study indicated that they prefer to study alone than with others. In the study of Boehler, et al [2], students who studied in groups performed significantly better than those who were not. In addition, low achievers seemed to have trouble with the mechanics of English. This is consistent with literature as cited in the study of Patrick, et al [13] where academically underprepared students have deficiencies in basic academic skills like English, Mathematics and reading.

Collectively, literature suggest that effective studying requires not only that the students possess knowledge of appropriate studying techniques and practices (study skills), but also sustained and deliberate effort (study motivation), self-regulation, ability to concentrate and a sense of responsibility for and value in one's own learning [5]. Hurlburt, Koeker and Gade [8] proposed that personal relationships and relevancy of subject matter, rather than concern for specific study habits, maybe key factors in addressing low academic achievements. As reported by the same author, confluent education can play a vital role in addressing this problem of student's deteriorating knowledge. Confluent education they say, should be understood as systemic in orientation, meaning, students should not be regarded as objects that can be formed into predetermined forms; rather students and teachers should work together to achieve a mutually empowering learning experience. Confluent education recognizes that educating the whole person in all of his facets encompasses intrapersonal, interpersonal, and societal development [4]. Literature suggest that peer group mentoring, symbolic and allegorical tales and cooperative group exercise revolving around real life issues contributes to a context where students are empowered and challenged according to their own individual developmental stages and learning styles. Research studies on confluent education as cited by Hurlburt, Koeker and Gade [8], suggested that confluent education improves educational climate, interpersonal relations and attitudes towards learning.

Hence, there is a need for learning institutions to direct their attention to the creation and implementation of strategies and other similar activities that would help students develop good study habits and positive attitudes towards learning. Institutions need to embrace the concept of a "learning community" by encouraging and institutionalizing parental, instructional, and peer-mentoring programs to develop good study habits and positive learning attitudes among high school students. This would involve the creation, implementation, and monitoring of the learning community and peer mentoring program, which will, in turn, establish such program as an integral part of the curriculum [1]. 


\section{IMPLICATIONS FOR PRACTICE}

The present study provides merit for comprehensive academic interventions to improve the study habits and attitudes of the students. Consequently, improving student's study orientation leads to academic success. In view of confluent education, an integral academic foundation must be designed to create an environment that provides opportunities that encourage the development of highly motivated, self-directed, lifelong learners.

From the findings of this study, academic intervention programs based on the theory of confluent education can be drawn. Provisions of remediation courses, academic learning centers, academic advising, personal counseling, academic and career skills can be regarded as helpful in improving students study habits and attitudes (Patrick, et al., (1988). Figure 1 illustrates the proposed framework for confluent academic intervention programs.

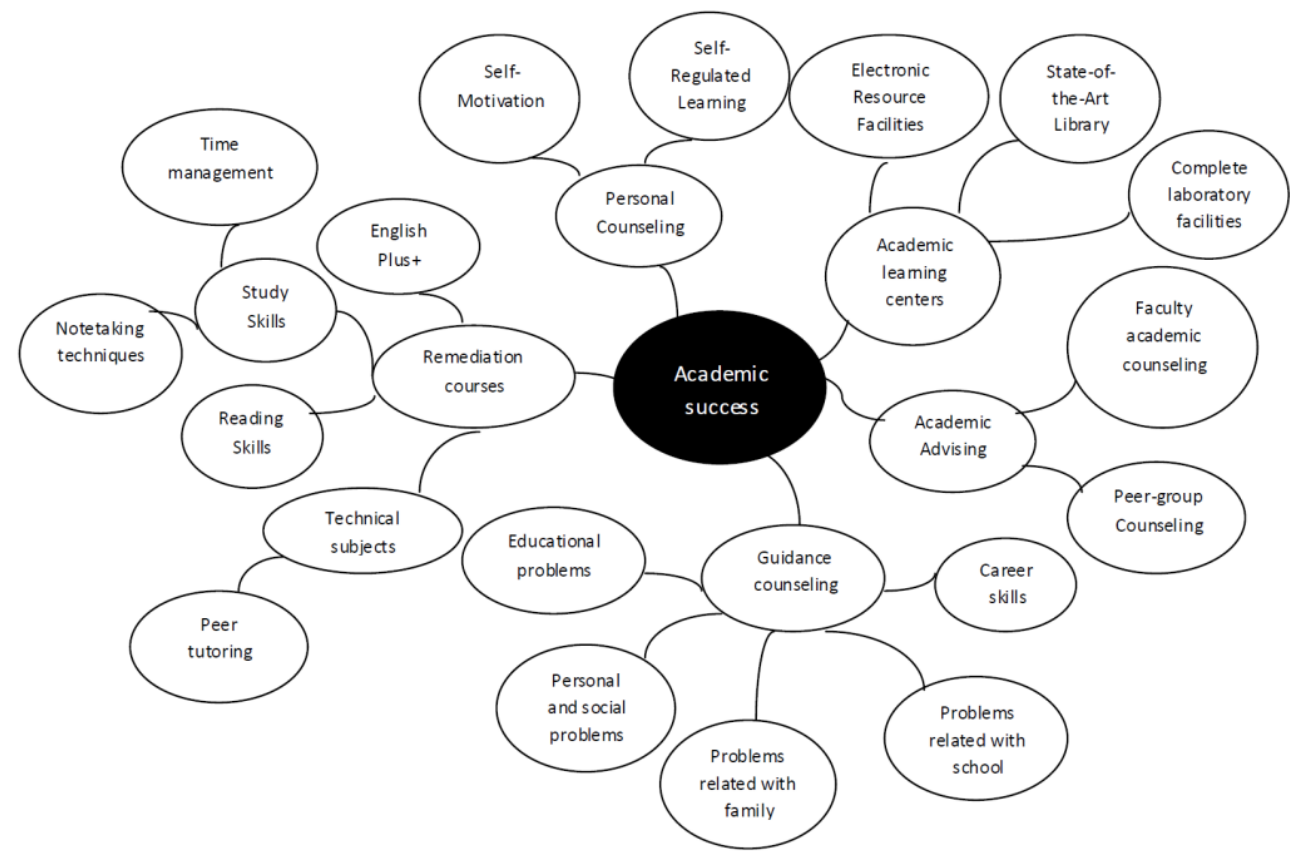

Figure 1. Confluent Academic Intervention Programs

First and foremost, classroom environment must be conducive for learning. Student's approval of teachers' methods and management are crucial to attain maximum classroom learning outcomes. In a practical sense, teachers need to consider adjusting his teaching strategies to suit to the learning styles of the students. Moreover, teachers should recognize the influence of student habit and attitude have on learning outcome with a view of monitoring and determining individual student learning problem for appropriate action. The responsibility of teachers goes beyond using appropriate teaching strategies and instructional materials in imparting knowledge. They also need to work towards enhancing the development of some personality factors (e.g. motivation) that have direct influence on the academic achievement of students. Students can be screened for level of academic self-efficacy or study habit or attitude at the beginning of a term. If they are low in the domain, teachers in conjunction with the guidance counselors can work with such students to promote and enhance their self-efficacy or study habit/attitude. The assumption is enhancing the constructs early will lead to better academic achievement and good success and retention rates.

It is recommended that guidance services where affective behavior of students can be properly monitored and worked on to all freshmen students to established a better academic foundation and facilitate the achievement of the objective of the universal basic education.

Academic departments must enforce academic advising among their teachers. Provisions on compulsory academic counseling for underachievers must be imposed. Academic departments or student organizations may consider giving more remedial actions to improve student's reading and study skills, time management, English and Mathematics aptitude, and or review classes on their technical subjects. Activities to motivate students to make personal counseling could also be considered.

Literature suggests that academic learning centers are vital in creating conducive learning environment. Thus, the institution should ensure contemporary academic learning centers like state-of-the-art libraries, complete electronic resource centers (e.g. internet, multimedia facilities), and all-inclusive laboratory facilities.

Finally, future research is needed to investigate how this learning environment that integrates the proposed framework for confluent academic interventions affects students' learning behavior and enhances students' educational development. Moreover, it is noted that the findings of this study are derived from a single cohort of students from the institution. Thus, the extent to which results are generalizable to other content areas, therefore, furthers future investigation. 


\section{REFERENCES}

[1] Acido, M., (2010). High School Students' Reasoning Skills and Their Study Habits and Attitude Towards Learning, Alipato: A Journal of Basic Education, Vol. 4 Available at http://journals.upd.edu.ph/index.php/ali/article/viewFile/1769/1685

[2] Awang, M. and Sinnadurai, (2010). A Study on the Development of Strategic Tools in Study Orientation Skills towards Achieving. Journal of Language Teaching and Research, Vol. 2, No. 1, pp. 60-67, Academic Excellence ISSN 1798-4769

[3] Boehler, M., et. al. (2001). An evaluation of study habits of third-year medical students in a surgical clerkship, The American Journal of Surgery Vol. 181 Issue 3, pp. 268-271 Available at http://www.academicjournals.org/ajpp/PDF/pdf2010/June/Orimogunje\%20et\%20al.pdf

[4] Brown, G. I., Phillips, M., \& Shapiro, S. B. (1976). Getting it all together: Confluent Education. Bloomington, IN: Phi Delta Kappa Educational Foundation.

[5] Crede, M., Kuncel, N. (2008). Study Habits Meta-Analysis, Perspectives on Psychological Science In Press vol. 3 No. 6 p. 425 453 Retrieved at www.psychologicalscience.org/journals/pps/3_6_inpress/crede.pdf Retrieved on May 13, 2010

[6] Gettinger, M., \& Seibert, J.K. (2002). Contributions of study skills to academic competence. School Psychology Review Vol. 31, 350-365.

[7] Hackbarth, S. L. (1997). Reflections on confluent education as discipline-based inquiry. Paper presented at the annual meeting of the American Educational Research Association, Chicago, IL. Available at http://www.eric.ed.gov/PDFS/ED409322.pdf

[8] Hurlburt, G., Kroeker, R., and Gade, E., (1991). Study Orientation, Persistence and Retention of Native Students: Implications for Confluent Education, Journal of American Indian Education Vol. 30 No. 3, Available at http://jaie.asu.edu/v30/V30S3stu.htm

[9] Hussain, A. (2006). Effect of Guidance Services on Study Attitudes, Study Habits and Academic Achievement of Secondary School Students, Bulletin of Education and Research Vol. 28, No.1 pp. 35-45

[10] Keller, M. (1978). Factors Affecting the Poor Academic Achievement of First-Term Freshmen at Miami (University). Retrieved from http://www.eric.ed.gov/ERICWebPortal Retrieved on September 8, 2010

[11] Nourian, A., et. al, (2008). Evaluation of study skills and habits in medical students, South East Asian Journal of Medical Education Vol. 2 No 1 Available at http://seajme.md.chula.ac.th/articleVol2No1/OR7_Abbasali\%20Nourian.pdf

[12] Ogunyemi, A. \& Hassan, E. (2011). Academic Self-Efficacy, Study Habit and Attitude in School-Based Assessment, African Journal for the Study of Educational Issues, Vol 4 Retrieved at http://ajeduionline.org/3-6.php, Retrieved on February 21, 2011

[13] Patrick, J., Furlow, J.W., and Donovan, S. (1988). Using a comprehensive academic intervention program in the retention of high risk students. NACADA Journal, Vol 8, p. 29- 34.

[14] Proctor, B., et. al. (2006). Study Skills Profiles of Normal-Achieving and Academically-Struggling College Students, Journal of College Student Development, Vol 4 No. 1, p. 37-51

[15] Riaz, A. Kiran, A., Malik, N. (2002). Relationship of study habits with educational achievements. International Journal of Agriculture and Biology, Vol. 4, No. 3, p. 370-371 Available at http://www.fspublishers.org/ijab/past-issues/IJABVOL_4_NO_3/18.pdf

[16] Sarwar, M., et. al. (2009). Study-orientation of high and low academic achievers at secondary level in Pakistan, Educational Research and Reviews Vol. 4 (4), pp. 204-207 ISSN 1990-3839 Available online at http://www.academicjournals.org/ERR

[17] Stark, Mary C. (2008). Retention, Bonding, and academic Achievements: Effectiveness of the college's seminar in promoting college success, Ninth Annual National Conference on Retention, New York. Available at http://www.eric.ed.gov/ERICWebPortal/search/detailmini.jsp?_nfpb=true\&_\&ERICExtSearch_SearchValue_0=ED374741\&E RICExtSearch_SearchType_0=no\&accno=ED374741

[18] Wai-yung, E. and Lailing, B. (1984). The Effects Of A Study Skills Programme On Academic Achievement, CUHK Education Journal Vol2 No. 1

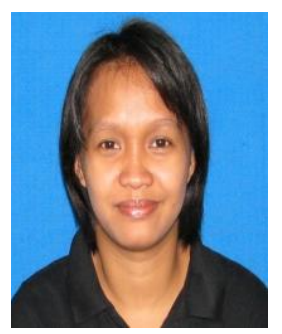

Luisa Baquiran Aquino is a member of the University Research Pool of the University of Saint Louis (USL), Tuguegarao City, Cagayan, Philippines. She finished her Masters in Information Technology in 2006. She is also a fulltime faculty of the School of Information and Computing Sciences. Her major fields are system analysis and design, database Systems and project management.

As a member of the University Research Pool, she has been involved in research related to educational and curriculum development. Her research interest covers software engineering and e-learning practice. 